\title{
КОРПУС ЛИНГВИСТИКАСИ МУСТАҚИЛ ФАН ТАРМОҒИ СИФАТИДА
}

\section{Ахмедова Анорхон Насивали қизи \\ Ўзбекистон давлат жахон тиллари университети ўқитувчиси anorxonimomalyeva@gmail.com}

Аннотация. Мазкур мақола корпус лингвистикасини мустақил фан тармоғи сифатида тадқиқ этишдан иборат. Мақолада, шунингдек, корпус лингвистикаси ва матн лингвистикасининг бир-бири билан алоқаси ва фарқли жихатлари ёритиб берилган.

Калит сўзлар: корпус лингвистикаси, корпора, матн лингвистикаси

Баъзи олимлар бу фанни тушунишни бироз қисқартириб уни компьютер лингвистикаси доираси билан чеклайдилар: “Корпус лингвистикаси - бу компьютер технологияларидан фойдаланган холда лисоний корпусларни (матн корпусларини) куриш ва улардан фойдаланишнинг умумий тамойилларини ишлаб чиқадиган хисоблаш лингвистикасининг бир бўлаги" [1].

Корпус лингвистикасини компьютер лингвистикасининг асосий йўналиши сифатида эътироф этиш мумкин, чунки матнни қайта ишловчи дастурлар корпусга асосланада [2].

Корпус - бу маълум бир тилда матнларни электрон шаклда тўплашга асосланган ахборот-маълумот тизими [3]. Корпус лингвистикасининг мақсади матн(лар) орқали амалга оширилиши билан бирга, тилдан фойдаланишни тахлил қилиш ва тавсифлаш каби жихатларига эьтибор қаратади. Корпус лингвистикаси Матн лингвистика билан бир хил асослардан бошланади бунда матнлар маъно яратиш учун асосий восита сифатида қаралади. Бироқ, шундай савол пайдо бўлади: Корпус тахлиллаарини худди шундай бахолаш мумкинми? Улар матн сифатида бахоланадими? Ушбу масала ханузгача хал қилинмаган. Турли олимлар бунга хар хил йўллар билан ёндашишмоқда ва ханузгача ўз фикрларини химоя қилаётганлар хам бор корпус маълумотларини яхшироқ тушуниш ва бахолаш, тахлилчига тўғридан-тўғри ва тўлиқ кириш хукуқига эга бўлиши, керак вақтнинг исталган нуқтасида алохида матнларни ўрганиши мумкин. 
Корпус ва матн лингвистикасининг бошланғич нуқтаси битта бўлишига қарамай, улар иккита ёндашув ва бир неча нуқтаи назардан тубдан фарқ қилади.

Firthian frameworkда контекстуал маъно назарияси доирасида иш олиб борилган матн ягона коммуникатив контекст икки (иштирокчилар тўплами) бирлаштирилган тил ходисаси воситачилик қилга, бирлаштирилган тил ходисаси сифатида қаралди. Матн лингвистикаси нуқтаи назардан корпус лингвистикага ўтишнинг ўзгариши бошқача ёндашувни келтириб чиқарди. Корпус худди матнга ўхшайди, фақат ундан кўпроқ деб тушунмаслик лозим. У жуда кўп турли хил матнларни бирлаштиради ва шунинг учун уни бирлашган ва изчил коммуникатив воқеа билан аниқлаб бўлмайди. Корпусдаги иқтибослар - контекстдаги калит сўздан (ККС) ${ }^{1}$ кенгайтирилган форматидаги $\boldsymbol{n}$ сонли сўзларни киритиш учун - матн парчалари бўлиб қолади ва матн бутунлигини йўқотади. Корпусдаги мухим элементлар такрорлаш нақшлари ва биргаликда танлов намуналарининг моделига айланади. Бошқача қилиб айтганда, корпус лингвистикасида бу ходиса частотаси аниқланиши билан Матн лингвистикасидан ажралиб туради.

Корпус матни нисбатан бошқача “ўқилишини” талаб қилади (Тогнини Бонелли 2001): ўзбек, инглиз ва бошқа кўпгина тилларда матн горизонтал равишда чапдан ўнгга, чегараларга яъни катта боб ёки бўлимларга, жумлалар ва хатбошилар, каби хусусиятларга эътибор бериб ўқилиши керак. Корпус эса матндан фарқли тарзда дастлаб ККС форматида марказда белгилаб олинган сўз текширилади ва корпус вертикал равишда ўқилади, тугун контекстида мавжуд бўлган такрорланган ККС сканерланади.

${ }^{1}$ Контекстдаги калит сўз кейинги ўринларда ККС тарзида берилади 


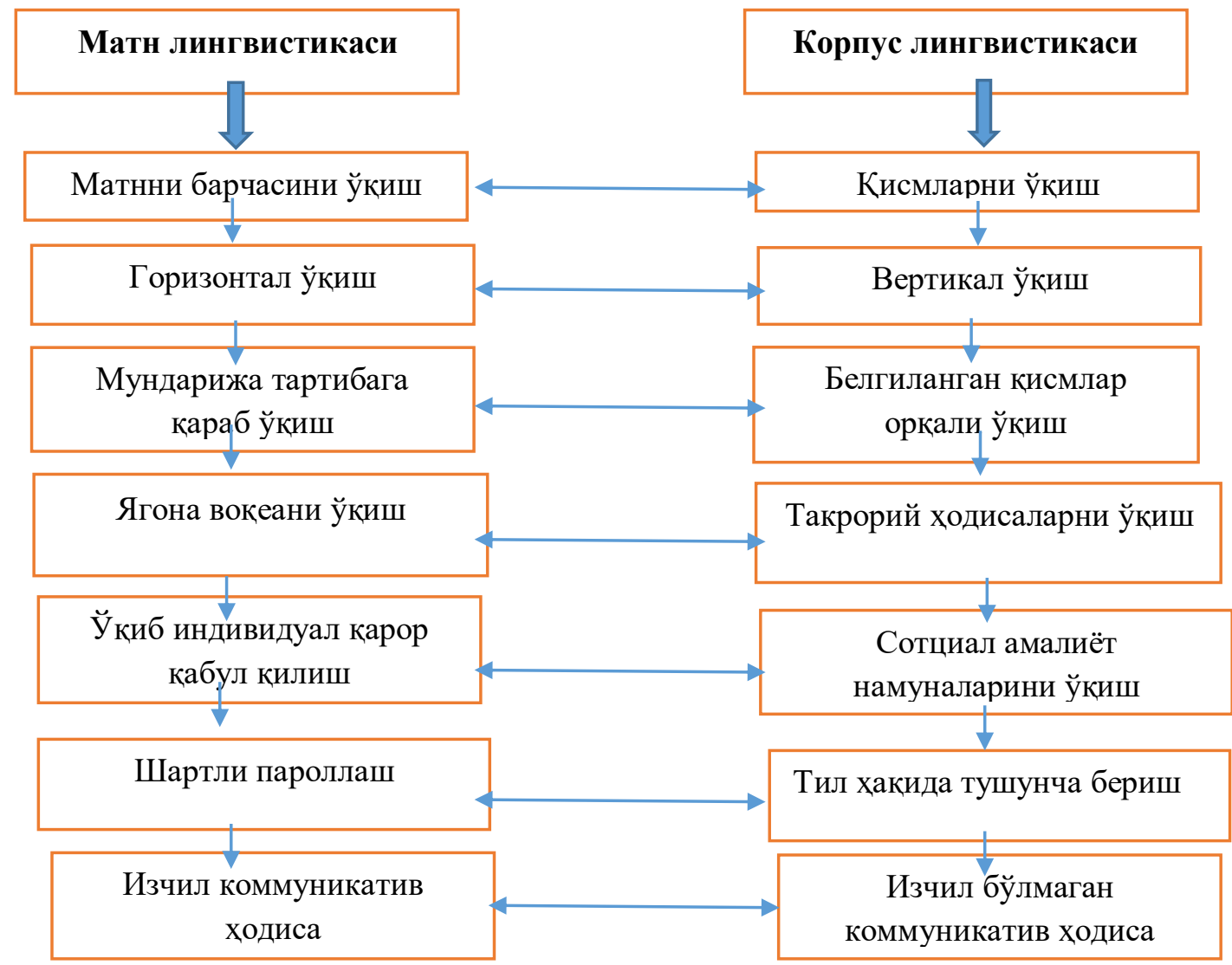

1.1. -жадвал. Матн лингвистикаси ва Корпус лингвистикаси хусусиятларини таққослайди.

Бундан ташқари, корпуснинг яна бир функцияси оғзаки(verbal) матнни хам ўзида мужассам этади. Контекстда амалга ошириладиган, шунингдек, вазият ва кенг маданий контекстга тааллукли функцияга эга. У коммуникатив ходиса сифатидаги функцияларига қараб изохланади. Бошқа томондан, корпус ягона функцияга эга эмас, фақатгина тўпланган тилнинг лингвистик тахлили намунаси бўлишдан ташқари, корпусни тахлил қилиш параметрлари формал хисобланади.

Матндан олинган маълумот тури оғзаки ва оғзаки бўлмаган харакатлар билан боғлиқ бўлган контекстда ва бундай харакатлар натижаларига нисбатан мазмунли деб талқин этилади.

Юқорида келтирилган корпус ва матн ўртасидаги фарқлар икки манбаанинг ўзига хос хусусиятларига асосланган бўлса хам баъзида ўхшашдек кўринади, аммао тахлилий жихатдан улар бир-биридан тубдан фарқ қилади. Корпус ўз ичига турли хил методологик тахлил тизимларнии қамраб олади албатта улар орасида махсус матнлар хам жойланади. Корпус 
тахлил қилувчига бир қанча афзалликлари бор, яъни конкорданс ${ }^{2}$ горизонтал ўқида ўқилиши ва кенгайтирилиши мумкин бўлган таглар ва конкорданснинг вертикал ўқи бўйича ижтимоий амалиётда такрорланган махсус белгилар намуналарини танлаш имкониятини яратади. Корпусда пайдо бўлиш частотаси фойдаланиш частотасини кўрсатади ва бу маълум бир сўз, тузилма ёки иборанинг профилини бахолаш учун яхши асос яратади. Горизонтал ўқда махаллий даражада синтагматик нақш солиш тасвирланган, вертикал ўқ эса парадигматик мавжудликни келтириб чиқаради; бу маърузачи ёки ёзувчи учун маълум бир вақтда ва маълум бир тил тизимида мавжуд бўлган танловдир.

\section{Фойдаланилган адабиётлар:}

1. Захаров В.П., Богданова С.Ю., КОРПУСНАЯ ЛИНГВИСТИКА: - 2011 Иркутск ИГЛУ

2. Abduraxmonova N.Z. Kompyuter lingvistikasi: - Meldrun: Globe edit, 2020. - Б. 283

3. Абжалова М. Ўзбек Миллий корпусининг тарихий асоси. “Филологиянинг долзарб муаммолари / The actual problems of Philology" мавзусидаги Халқаро илмий-амалий интернет конференция. - Фарғона, 2020. - В. 74-76.

4. Атабоев Н.Б. Инглиз тили корпусининг функционал хусусиятлари (СОСА мисолида) дис...ф.ф.док. -Тошкент, 2020. - 189 б

5. Френсис У.Н. Проблемы формирования и машинного представления большого корпуса текстов // Новое в зарубежной лингвистике. Выпуск XIV. Проблемы и методы лексикографии. - М.: Прогресс, 1983.

6. McCarthy M. O'Keeffe A., The Routledge Handbook of Corpus Linguistics:- New York, 2010.

${ }^{2}$ Конкорданс - матндан намунаолар топиш 